\title{
Sir William Wilde's Medico-Legal Observations
}

\author{
J B LYONS*
}

If to be arraigned for murder, strikes the most hardened villain with horror, what must the innocent culprit suffer? . . . who, prosecuted perhaps through malignity, and impeached through ignorance, finds his conviction from mistaken prejudice, become a public wish. ${ }^{1}$

The career, avocations and misfortunes of Sir William Wilde (1815-76) are described by his biographers ${ }^{2}$ and others, ${ }^{3}$ but recently a forgotten facet of his activities has been recovered. This is his successful support of Patrick Kane, a Dublin coachman accused in July 1853 of sexual assaults on two little girls, an intervention followed some years later by Wilde's appeal on behalf of Amos Greenwood, a Lancashire costermonger's assistant found guilty of manslaughter at the Liverpool Assizes in 1857. What may be called Wilde's medico-legal observations have given rise to surprisingly little comment, and are the subject of the present article.

His fortuitous mediations may be seen merely as unusual events in the career of a highly unusual person, ${ }^{4}$ but merit consideration, too, in the broader context of forensic medicine, a developing speciality which in the process of educational reform was gaining in importance throughout the first half of the nineteenth century. ${ }^{5}$ (A few years before Wilde entered the RCSI, Abraham Colles had advised that a chair of medical jurisprudence should be created there, the second chair of its kind in the United Kingdom. ${ }^{6}$ John Adrien, its first incumbent,

*Professor J B Lyons, Department of the History of Medicine, RCSI, The Mercer Library, Lower Mercer Street, Dublin 2, Ireland.

\footnotetext{
1 [William Dease], Remarks on medical jurisprudence intended for the general information of juries and young surgeons, Dublin, 1793. This unsigned pamphlet is attributed to Dease, president of the Royal College of Surgeons in Ireland (RCSI) in 1789, by the Dublin Medical and Physical Essays, 1807, 1: 249. On the title-page of the copy of the pamphlet in the RCSI's library Dease's name is penned in by Abraham Colles.

2 T G Wilson, Victorian doctor, London, Methuen, 1942; Terence de Vere White, The parents of Oscar Wilde, London, Hodder and Stoughton, 1976. See also, Joy Melville, Mother of Oscar, London, John Murray, 1994.

${ }^{3}$ Wilde's antiquarian pursuits, connection with the census and biographical interests have been discussed respectively by Liam de Paor, The Irish Times, 14 Sept. 1976, p. 8; Sir Peter Froggatt, 'Sir William Wilde and the 1851 census of Ireland', Med. Hist., 1965, 9: 302-27; J B Lyons, 'Sir William Wilde, 1815-1876', in “What did I die of?" , Dublin, Lilliput Press, 1991, pp. 64-91.
}

\footnotetext{
4 A memorial plaque at 1 Merrion Square, Dublin, Wilde's residence from 1855 to 1876 , lists his accomplishments: aural and ophthalmic surgeon, archaeologist, ethnologist, antiquarian, biographer, statistician, naturalist, topographer, historian, folklorist.

${ }^{5}$ See Catherine Crawford, 'Medicine and the law', in W F Bynum and Roy Porter (eds), Companion encyclopaedia of the history of medicine, 2 vols, London, Routledge, 1993, vol. 2. See also, P J Bofin, 'The evolution of forensic medicine', J. Irish Colls Phys \& Surgs, 1973, 2: 76-82.

${ }^{6}$ A chair of legal medicine was established in Paris in 1795; Vienna had a chair of forensic medicine and medical police from 1804; a professorship of medical jurisprudence and medical police was established within the faculty of law at Edinburgh in 1807. The Society of Apothecaries in London introduced compulsory lectures in 1831; a regius chair of medical jurisprudence and medical police was reluctantly accepted in 1839 by the faculty of medicine in Glasgow University. See M Anne Crowther and Brenda M White, On soul and conscience, Aberdeen University Press, 1988, pp. 8-11.
} 


\section{J B Lyons}

was appointed in 1829). ${ }^{7}$ One must ask if Wilde's involvements with medico-legal matters are a commendable, if unexpected, extension of his connection with medical journalism. ${ }^{8}$ It should be queried whether the irregularities of his private life are relevant. Present-day readers will quickly recognize the impact of a gender factor which can interpose difficulties when the rape of children is in question: the Dublin working-class mothers appeared so ready to accuse; Wilde and his professional associates were for the most part eloquent on the defendants' behalf despite an absence of authoritative guide-lines for the handling of child sex-abuse cases. ${ }^{9}$

\section{Infantile Leucorrhoea}

In the early 1850 s, Wilde, an established eye-and-ear surgeon, was approaching forty ${ }^{10}$ and from 1845 to 1849 had served as editor of the Dublin Quarterly Journal of Medical Science in which he wrote on the famine fevers and the epidemic of ophthalmia, a major cause of blindness in the workhouses of Tipperary and Athlone. He had a talent for the

\footnotetext{
${ }^{7}$ See J D H Widdess, The Royal College of Surgeons in Ireland and its Medical School 1784-1984, Dublin, RCSI, 1984, p. 72. Adrien (1798-1830) was succeeded by Thomas E Beatty (1799-1872) who had lectured on medical jurisprudence in the Richmond Hospital School. Thomas G Geoghegan held the chair 1835-69.

${ }^{8}$ For the contribution of medical editors to the development of medical jurisprudence see Catherine Crawford, 'A scientific profession: medical reform and forensic medicine in British periodicals of the early nineteenth century', in Roger French and Andrew Wear (eds), British medicine in an age of reform, London, Routledge, 1991. They expressed dissatisfaction with the judiciary's tendency to give equal weight to the opinions of lay and medical witnesses, disapproved of the latter's appearance in court unprepared for stringent cross-examinations, and deplored disagreements over what were supposedly matters of science.

Opportunities to redress the situation were taken in reports of trials, reviews and leading articles. Thomas Wakley (1795-1862) referred to “coroners' courts with crowds of incompetent, juvenile, babbling, medical witnesses". See 'Forensic medicine as a test of knowledge', Lancet, 1831-2, i: 621-4.

${ }^{9}$ Samuel Farr (1741-95), author of the first book in English (1788) on medical jurisprudence, accepted that children were sometimes raped but did not enlarge on the subject. (S Farr, Elements of medical jurisprudence, 3rd ed., London, Callow, 1815, p. 46.) William A Guy (1810-55), professor of forensic medicine to King's College Hospital, London, discussed difficulties in securing convictions at a time when both penetration and emission had to be established; he referred to a number of cases where children were violated. (W A Guy, Principles of forensic medicine, London, Renshaw, 1844, pp. 49-67.) Alfred Swaine Taylor (1806-80), professor of medical jurisprudence at Guy's Hospital, editor of the London Medical Gazette (and a pioneer of photography), offered an account of rape at various

ages including childhood (A S Taylor, Medical jurisprudence, 3rd ed., London, Churchill, 1849, pp. 630-5). See also, John Glaister, A text-book of medical jurisprudence, toxicology and public health, Edinburgh, Livingstone, 1902; Susan Brownmiller, Against our will, Harmondsworth, Penguin Books, 1976; Jane Roberts Chapman and Margaret Gates (eds), The victimization of women, London, Sage Publications, 1978; Sylvana Tomaselli and Roy Porter (eds), Rape, Oxford, Blackwell, 1986.

10 The youngest son of Dr Thomas Wilde of Castlerea, County Roscommon, William Wilde (1815-76) was apprenticed to Abraham Colles. He took the Letters Testimonial of the RCSI in 1837 (FRCSI 1844), and accepted a post as physician to a wealthy invalid going on a health cruise. The interlude between student-days and practice provided material for The narrative of a voyage to Madeira, Teneriffe, and along the shores of the Mediterranean (1839), which brought him $£ 250$, enabling him to study eye and ear surgery in London, Vienna and Berlin. On his return to Dublin he set up in practice at 15 Westland Row, opened a dispensary for poor patients (the forerunner of St Mark's Ophthalmic Hospital) in a converted stable, and engaged in a variety of avocations (see note 4 above). His Practical observations on aural surgery was published in 1853, in which year he was appointed Surgeon Oculist in Ordinary to the Queen in Ireland. Additional honours included the Order of the Polar Star, bestowed by Carl $\mathrm{XV}$, king of Sweden (1862) probably on the recommendation of the Wildes' friend Baron von Kraemer, Governor of Uppsala (Melville, op. cit., note 2 above, p. 79); a knighthood (1864) for his work in connection with Irish censuses; and the Cunningham Gold Medal, the Royal Irish Academy's highest award (1873). Sir William and Lady Wilde defended a libel suit taken by Miss Mary Josephine Travers, a former patient, in 1864 (notes 86 and 91 below). Wilde's health deteriorated in 1875; he died on 19 April 1876 and was buried in Mount Jerome Cemetery.
} 


\section{Sir William Wilde's Medico-Legal Observations}

compilation of lengthy documents of this kind, and a compulsion, it would appear, to issue them, a mild example perhaps of cacoëthes scribendi. His 'History of the recent epidemic of infantile leucorrhoea', ${ }^{11}$ published in four successive numbers of the Medical Times and Gazette in the autumn of $1853,{ }^{12}$ was followed by a pamphlet on the same theme, Medico-legal observations upon infantile leucorrhoea (1853). ${ }^{13} \mathrm{His}$ purpose in publishing these observations was to draw attention to the danger of leucorrhoea in children leading to unfounded criminal charges. He cited in this regard the influential writings of Sir Astley Cooper, ${ }^{14}$ who in his lectures at Guy's Hospital gave a detailed description of the not uncommon, and easily misunderstood vulval discharge. "It now and then happens to a nervous woman, to be alarmed at such an appearance, and she suspects her child of having acted in an improper manner . .. ". The consequences may be terrible. "I am anxious", Cooper told his students, "that this complaint should be known by everyone present, and that the remarks I have made should be circulated throughout the kingdom."15

A common sequel to the appearance of a genital discharge in a child, according to Wilde, was the mother's suspicion that her daughter had been sexually molested, a fear sometimes reinforced if an inexperienced doctor mistook the condition for "the clap", 16 and further aggravated by the recollection of a superstitious belief that through intercourse with a virgin a man could rid himself of a venereal infection, transferring it to the girl. ${ }^{17}$ The child was immediately interrogated by her distressed and angry parent, vociferously assisted by the women of the neighbourhood, and questioned as to who had interfered with her. All denials were ignored; the names of men known to be fond of children, and

\footnotetext{
${ }^{11}$ By the mid-nineteenth century "infantile leucorrhoea" was an established clinical entity. Children of "a strumous habit" were regarded as prone to muco-purulent or purulent discharges from the vulva and vagina, which Evanson and Maunsell also related to "a deranged condition of the bowels". Others mentioned dentition, worms and the exanthemeta as causative factors. All cautioned that discharges in little girls could be misinterpreted, with serious social consequences. (R T Eyanson and H Maunsell, A practical treatise on the management and diseases of children, Dublin, Fannin, 1838, p. 448). See also, E C Dillon, 'Simulation of gonorrhoea in children', Lancet, 1836-7, i: 789; Fleetwood Churchill, On the diseases of women including those of pregnancy and childbed, 3rd ed., Dublin, Fannin, 1850, pp. 33-4; C West, Lectures on the diseases of infancy and childhood, London, Longman, Brown, Green, and Longmans, 1854, p. 552; $\mathrm{T} \mathrm{H}$ Tanner, A practical treatise on the diseases of infancy and childhood, London, Renshaw, 1858, p. 367.

$12 \mathrm{~W}$ R Wilde, 'History of the recent epidemic of infantile leucorrhoea', Med. Times Gaz., 1853, 7: 260-2, 346-8, 369-71, 446-9.

13 Wilde, Medico-legal observations upon infantile leucorrhoea, London, Churchill, Dublin, Fannin, [1853]. It opens with an introduction, reprints the text of the article in the Med. Times Gaz, and gives details of the replies to a questionnaire sent to colleagues.
}

\begin{abstract}
14 A figure of great authority, Sir Astley Cooper (1768-1841) was surgeon to Guy's Hospital. His account to students of "a discharge from young females", and the misapprehensions arising, is quoted in Wilde's pamphlet. Cooper encountered possibly thirty cases mistaken for the rape of a child, then a capital offence. "The mother is persuaded, if there be a slight ulceration in the parts, that violence has been used, and a rape committed; she immediately says, "What a horrid villain must he be for forcing a child to such an unnatural crime, and communicating to her such a horrible disease! I should be glad to see him hanged!'" See Wilde, op. cit., note 13 above, p. ix.

${ }^{15}$ Sir A Cooper, Bart., Lectures on the principles and practice of surgery, 6 th ed., London, Churchill, 1839, pp. 541-2.

${ }^{16}$ Even experienced doctors were unable to distinguish a non-specific muco-purulent discharge from gonorrhoea by simple inspection. Fleetwood Churchill (op. cit., note 11 above, p. 51) wrote: "But as I know no sure means of distinguishing infantile gonorrhoea (if there be such a thing) from infantile leucorrhoea, the case must be decided independent of medical testimony."

17 Wilde did not mention this baleful tradition in his paper, "A short account of the superstitions and popular practices relating to midwifery, and some of the diseases of women and children, in Ireland', Monthly J. med. Sc. [Edinburgh] 1849, 9: 712-26.
\end{abstract}


generous with pennies and sweets, were reviewed, and the badgering continued until grounds for a charge were established and the police informed.

The medical background to the first ${ }^{18}$ of a series of cases tried in Dublin in 1853 (Regina $v$. Tracey), in which a Dublin solicitor's butler, P Tracey, was accused of violating a beggar child to whom he regularly gave bread, is supplied by John Hamilton, FRCSI:

Catherine Geogahan, a remarkably intelligent child, seven years old, was brought to me, March 9, 1853, to the Richmond Hospital, by the police, as having been violated: the man suspected of the offence was in custody. She was pale, but not delicate-looking. The crime was said to have been committed a fortnight before. Her story, which she detailed very glibly, being that he had taken her into his office, let down his breeches, and put his thing to her thing; but that he had not hurt her much. Both labia were red and swollen, and on the inner aspect soddened-looking. On the prominent cuticular edge of each, were a number of small superficial sores. Some of these small ulcers were round, but the greater number irregular; the surface yellow, the edges and margins red. An excoriated appearance extends from the lower end of the vaginal opening to the anus. ${ }^{19}$

There was a yellowish vaginal discharge, but no sign of laceration or bruising of the vaginal aperture.

Hamilton found no evidence of violence, and the child did not claim to have experienced pain, leaving him to decide whether by non-violent contact an infection could have been communicated- "whether, in fact, the yellow discharge was gonorrhoeal, and whether the small ulcers were chancres." This question could not be answered by inspection alone, and he was influenced by the little girl's general appearance. She was itchy and verminous, "her whole person dirty in the extreme". 20

Meanwhile, Hamilton had learned from the police doctor that the prisoner was free from signs of disease, and his final conclusion was that the sores were itch ulcers, the discharge "the product of simple scrofulous vaginitis". Both responded to treatment with sulphur ointment, black wash and vaginal douches. ${ }^{21}$

\footnotetext{
18 Charges of rape, according to Wilde, were "brought forward almost daily" in rural Ireland by women who "have cohabited with men, or are at the time pregnant by them, in order to procure a marriage" (op. cit., note 13 above, p. v). Be that as it may, reported cases of child rape were probably infrequent in eighteenth- and nineteenth-century Ireland. Paul O'Higgins refers to just one trial, Rex $v$. Hogan, 1726: 'A full and true account of the tryal of John Hogan, a butler to Squire Gaskin, for endeavouring to commit a rape on the two small children of the said Gaskin conveying to them the foul disease and poxing a male child, whereof he was found guilty at the Assizes of Naas, last Saturday.' (Paul O'Higgins, A bibliography of Irish trials and other legal proceedings, Abingdon, Professional Books, 1986, pp. 4, 98.) But Anna Clark (Women's silence, men's violence, London, Pandora, 1987. p. 98) states that "court records vastly underestimate" the incidence of nineteenth-century child sex abuse. See also, Mark Cook and Kevin Howells (eds), Adult sexual interest in children, London, Academic Press, 1981; James Kelly, “"A most inhuman and barbarous
}

\author{
piece of villainy": an exploration of the crime of rape \\ in eighteenth-century Ireland', Eighteenth-Century \\ Ireland, 1995, 10: 78-107; Wendy Holden, Unlawful \\ carnal knowledge, London, HarperCollins, 1994. \\ 19 John Hamilton, "Two cases in which children \\ were said to have been violated and diseased', \\ Dublin med. Press, 1853, 29: 276-7. Hamilton was \\ surgeon (1844-75) to the Richmond Hospital, where \\ on New Year's Day 1847 he was one of John \\ MacDonnell's assistants at the first operation \\ performed in Ireland under ether anaesthesia. Later \\ in 1847 Hamilton was the first in Ireland to use a \\ chloroform anaesthetic. His papers included 'On \\ syphilitic sarcocele' and 'The restoration of a lost \\ nose'. See E O'Brien in The house of industry \\ hospitals 1772-1987: . . a closing memoir, \\ compiled by E O'Brien, L Browne and K O'Malley, \\ Dublin, Anniversary Press, 1988, pp. 56-7. \\ ${ }^{20}$ Hamilton, op. cit., note 19 above, p. 276. \\ ${ }^{21}$ Black wash (Lotio hydrargyri nigra) contained \\ mercurous chloride $7 \mathrm{~g}$., glycerin $50 \mathrm{ml}$., solution of \\ calcium hydroxide to $1000 \mathrm{ml}$.
}




\section{Sir William Wilde's Medico-Legal Observations}

The child swore the interference occurred in an office adjoining the dining room, where at the time the family were seated. Her evidence broke down during the trial; the butler was freed but his employment was terminated to rid his employer of an unhappy association. A second case seen by Hamilton, which will be referred to later, led to a remarkably lenient prison sentence.

Wilde blamed the hot July of 1853 for a minor epidemic of vulvo-vaginitis among slum children. One of these, nine-year-old Margaret Walsh, presented florid symptoms and was "soundly flogged" for her silence when her step-mother demanded the name of the man responsible for her condition. The crucifix was taken down from the mantelpiece and placed before her. Neighbouring women suggested various names, and finally Margaret's elder sister reminded her of a military pensioner, named Barber, who had given her "a bit of sugar" some months before. When she agreed, the process of accusation began.

"The mother and child rushed to the police-office; the accused was immediately arrested, carried before the magistrate, and, upon the evidence of the child and the police doctor, committed for trial and sent to prison."22 Margaret said Barber had taken her into the open hall of an adjoining house, and offered details Wilde found "too disgusting to be quoted". ${ }^{23}$ She swore to having sex with him several times during the previous eighteen months. ${ }^{24}$

\section{Regina v. Kane}

Bridget Cosgrave, a nine-and-a half-year-old child, and her younger friend, Anne Delmere, who lived in a lane that ran behind 21 Westland Row where Wilde and his wife (the celebrated "Speranza") then resided, ${ }^{25}$ were victims of the epidemic. When Mrs Cosgrave learned that her daughter was "very sore", and saw the soiled condition of her underwear (unchanged for eleven days), she asked who had been meddling with her. Bridget denied interference, but was told she would be taken to the doctor, "and that the doctor would cut the tongue out of her head if she did not tell what had occurred to her." 26 After two days' questioning the girl ceased to plead innocence, and when Mrs Cosgrave named Patrick Kane, a coachman who lived in the lane with his wife and family, as a suspect, the youngster fell in with her prompting. Having done so, she appears to have become a fervent and inventive accomplice. Not only did her imagination provide a vivid account of Kane's alleged misdoings, but she immediately passed on to Anne Delmere what she had said, and her version of how he had taken her up a ladder into the hay-loft.

\footnotetext{
22 Wilde, op. cit., note 12 above, p. 261.

23 His repugnance, genuine or rhetorical, accords with Michael Mason's observation that disgust was commonly experienced by Victorian practitioners faced with the discussion of sexual irregularities. "There was recognised to be a vacuum of sexual information, into which the profession at all levels stepped." (M Mason, The making of Victorian sexuality, Oxford University Press, 1994, p. 193.) Sexual prudery has been noted as a common feature of the "authoritarian personality". See Mark Harrison, 'The British army and the problem of venereal disease in France during the first world war', Med. Hist., 1995, 39: 133-58.
}

\author{
24 See note 43 below. \\ 25 Wilde married Jane Francisca Elgee in 1851 and \\ moved to 21 Westland Row. They had three children, \\ William (1852-99), Oscar (1854-1900) and Isola \\ (1857-67). "Speranza's" patriotic verses were \\ published in The Nation, a political and cultural Irish \\ periodical (1842-96) founded by Sir Charles Gavan \\ Duffy (1816-1903), Thomas Davis (1818-45) and \\ John Blake Dillon (1816-66) to represent the Young \\ Ireland Movement. \\ ${ }^{26}$ Wilde, op. cit., note 12 above, p. 262.
}




\section{$J$ B Lyons}

Patrick Kane was employed by Wilde. It was his custom, when driving to and from the stables, which he did at regular hours, to take local children up beside him on the box, and occasionally he allowed them to go up to the hay-loft to look at some kittens, a geniality which was to be cruelly misinterpreted by the distracted mothers, Mrs Cosgrave and Mrs Delmere. They went to the police during the night and had Kane taken out of his bed. Next morning ( 23 July) each child told her story separately in the police office, alleging that Kane had taken her up to the hay-loft and had done unexpected things to her, using certain expressions, before bringing her down again.

Although Wilde regarded Kane as a man of unblemished character, he did not seek bail for his employee immediately. Instead, he sought the advice of a leading solicitor, Mr Charles Fitzgerald, and applied to the presiding magistrate, Mr Richard Bourke, for permission to attend an examination of the children by Dr Richard S Ireland, the police doctor. ${ }^{27}$ Although this was granted, Ireland refused to have Wilde join him, but after the examination said the children had profuse discharges from the genitals, and Kane was free from disease.

The examining magistrate subsequently interrogated the children, using leading questions: "Did the prisoner lay you down?" "Did he take down his breeches?" "Did he take up your petticoats?" "Did he lie down upon you?" "Did he put his private parts into yours?". Each question was answered by the children individually with a simple affirmative. Wilde believed they would have said "yes" to the most preposterous question put to them. ${ }^{28}$

Dr Ireland, when examined before the magistrate, said he was uncertain whether the disease was gonorrhoea or not; subsequently he swore the discharge, etc., "might be occasionally the result of dirt or 'riding upon a stick'."29 Despite the absence of lacerations or other evidence of attempts at penetration, he believed such appearances could be the result of violence. This evidence led the magistrate to send the cases for trial, much to Wilde's surprise and disappointment.

Dissatisfied with the police investigation, and convinced they were dealing with "a trumped-up story", Wilde consulted Dr Thomas G Geoghegan, an active professor of medical jurisprudence at the RCSI, ${ }^{30}$ with whom he arranged to examine the girls in Dr Ireland's presence. "As soon as I saw the children", Wilde wrote, "and recognized the disease under which they laboured, I at once saw the mistake that had been committed." 31 He offered bail for Kane, and set about organizing the coachman's defence.

He enlisted the services of Professor J W Cusack, a leading surgeon, ${ }^{32}$ Dr Fleetwood Churchill, an obstetrician and authority on the diseases of children, and Dr George

\footnotetext{
${ }^{27}$ Dr Richard Stanley Ireland (c. 1790-1876), FRCS Eng. and I., took his primary diploma in 1818 . Senior MO to the police, he lectured on physiology, midwifery and diseases of women and children at the Original School of Medicine, one of many unchartered or private schools that flourished in Dublin in the eighteenth and nineteenth centuries. For an account of the private schools of medicine see $\mathrm{Sir} C \mathrm{C}$ Cameron, History of the Royal College of Surgeons in Ireland, 2nd ed., Dublin, Fannin, 1916, pp. 647-79.

${ }^{28}$ Wilde, op. cit., note 12 above, p. 262.

${ }^{29}$ Ibid., p. 346.

${ }^{30}$ Geoghegan had a laboratory in the College. "Many interesting cases in toxicology and forensic medicine came under his notice, and some of them are recorded in the Dublin Journal of Medical Science, the
}

\footnotetext{
Medical Gazette, and the Medical Press. In Taylor's works on Toxicology, etc., his name is frequently mentioned", Cameron, op. cit., note 27 above, p. 599.

${ }^{31}$ Wilde, op. cit., note 12 above, p. 346.

32 James William Cusack (1788-1861) was a figure of authority, three times PRCSI, and from 1852 regius professor of surgery in Trinity College Dublin. His eminence and popularity attracted many apprentices and when these reached fifty-two in number his pupils conferred on him the honorary rank of "Colonel of the 52nd". He had been one of Wilde's instructors at Dr Steevens' Hospital and the Park Street School of Medicine. Cusack was consulting surgeon to St Mark's Ophthalmic Hospital.
} 


\section{Sir William Wilde's Medico-Legal Observations}

Hatchell, the Medical Officer to the Constabulary. Having provided them with copies of the sworn "informations", he sent them to examine the children and the accused. The doctors acting for the defence were then requested to complete a questionnaire drawn up by Wilde who subsequently wrote: "the answers of these four eminent authorities completely exonerated the accused, and showed, as far as medical evidence could show, that the crime had never been committed". ${ }^{33}$ Fortified with this evidence, Wilde prepared a written statement incorporating a cast-iron defence based on medical evidence, and on an alibi which showed that Kane was elsewhere when the crime was alleged to have been perpetrated. Calling on the attorney general, John Hatchell, he ventured tactlessly to argue the case, requesting that it be quashed. This may have put the lawyer's back up, for Wilde was told "corroborative proofs" of the children's statements existed, and it would not do to cancel the trial of a doctor's servant because other medical men had come forward to support him. "I, therefore, took my leave," Wilde recalled, "assuring my friend, the Attorney-General, that I would certainly defeat him at the prosecution."34

Three barristers refused the brief, saying it was nasty, and difficult to defend. Others were engaged, and the array of QCs acting for the prosecution when the hearing opened on 5 August was formidable. Stating the case with moderation, the Honourable $\mathrm{Mr} \mathbf{J}$ Plunket, QC, admitted the previous good character of the defendant, and said the principal question was a medical one, the nature and cause of the disorder which the children presented. Bridget Cosgrave behaved impressively in the witness-box, explaining why she was so sure of the exact hour, and denying any hesitation in telling her mother about the cause of her affliction. She admitted, however, that her mother was the first to use Kane's name. Mrs Cosgrave and the elder daughter contradicted themselves and the child, on a number of points. The mother said Bridget had come home crying at the critical time, but conceded that a painful whitlow could have caused the tears, and agreed that the child walked to Ship Street that afternoon to visit a relative.

Dr Ireland said an adult's penis could not enter the child's vagina but could go between the labia, the diseased parts. ${ }^{35} \mathrm{He}$ was uncertain of the nature of the disease but thought external irritation caused by a man's penis could cause it. "I am of opinion", he said, "that the discharge may have been produced by friction with the penis of a healthy man." 36 The prosecution scored heavily with this affirmation, and when Mr Curran, for the defence, attempted to offer Sir Astley Cooper's evidence as to the frequency of vulvo-vaginitis as an innocently-acquired entity, the Lord Chief Justice stopped him and said: "it was not law nor evidence but only a Medical man's opinion". 37

The defendant's expert witnesses countered Dr Ireland's evidence. "I was as convinced", said Mr Cusack, "as I am of my existence that there was no violence offered or attempted upon this child, and that this was a common disease, which is universally known to the profession." ${ }^{38}$ Cusack spoke with great conviction, yielding nothing to cross-examination, and to Wilde's logical, scientific mind it seemed that the crown must now abandon the case. Far from doing so, the assault was renewed, and later in the trial

\footnotetext{
${ }^{33}$ Wilde, op. cit., note 12 above, p. 346.

34 Ibid., p. 347.

35 By the 1850 s it was accepted that penetration of this degree sufficed to constitute rape. See John Adams, 'What acts are essential to constitute rape?',
}

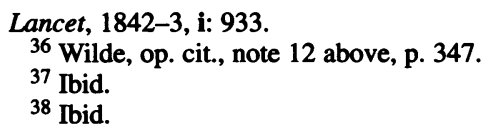


Wilde realized that even the defence lawyers were not really concerned with the elucidation of truth: their task was "to get off the prisoner". 39

Professor Geoghegan swore the Cosgrave child had a chronic disease of several weeks' standing. He added: "If violence had been committed upon this child by a man lying on her upon the hay, so as to hurt her in that way, I think she would not be able to walk over to Ship Street in the evening, and home again the next morning." 40 Dr Churchill insisted that the disease was ordinary infantile leucorrhoea.

In his cross-examination, $\mathrm{Mr} \mathrm{J}$ R Corballis, QC, appeared to make a considerable gain for the prosecution by eliciting grudging affirmatives from Drs Geoghegan and Churchill when he asked them if it were possible, supposing the child to have had the disease at the time of the alleged rape, that a man could have introduced the tip of the penis between the labia on 15 July. To establish the possibility of even minimal penetration was a tactical victory.

The defence counsel now sensed that the medical evidence was making little impact, and they insisted that the use of the alibi should not be postponed any longer. Mr Charles Rolleston, QC, acting for the prisoner, called a lady (presumably Mrs Wilde ${ }^{41}$ ) who swore that at the time when the crime was alleged to have been committed, Patrick Kane was actually driving her about the city. This witness was subjected to a long crossexamination, but it remained clear that the usual time for the coachman's return to Westland Row had changed on Friday 15 July, and he was away from the stables for six hours.

"Why didn't you give us the alibi first," the Lord Chief Justice asked, "instead of treating us to a medical dissertation?" 42 He directed the jury to acquit the prisoner. ${ }^{43}$

\section{The Freeman's Journal}

Regina $v$. Kane attracted considerable attention, and on 6 August The Freeman's Journal, the proprietor of which was Dr (later Sir) John Gray, a medical graduate, reported that on the previous day "Two cases were brought forward at Green-street, the details of which are of so disgusting a nature that we cannot pollute our pages with them"; the proceedings were backed by "insufficient evidence" and represented "an endeavour on the

\footnotetext{
39 Wilde would have favoured the Roman-canon law system used in trials in continental Europe. It relied on experts to a degree not followed in England, where the existing common law necessitated the use of juries. "Medical practitioners who assisted at continental Europe trials were ... officials of the court. Their reports, too, had official status, for they were an essential part of the trial dossier." Crawford, op. cit., note 5 above, p. 1626.

${ }^{40}$ Wilde, op. cit., note 12 above, p. 348.

41 The witness's name was not given either by Wilde, or by the newspapers which reported the trial, the transcripts of which have not survived. Saunder's News-letter, Sat. 6 Aug. 1853, merely stated that "a clear and distinct alibi" was proved; The Dublin Evening Post, Sat. 6 Aug. 1873, was equally terse. Circumstantial evidence suggests that Jane Francesca Wilde was the lady who was being driven about by
}

Kane. Wilde's mother, who had kept house for him at 15 Westland Row, was no longer alive, and his wife, now the mother of a son, was the only person likely to need the coachman's services for several hours.

42 Wilde, op. cit., note 12 above, p. 348.

43 When Barber, the old soldier, was eventually arraigned, the police doctor, influenced by the preceding case, accepted the diagnosis of leucorrhoea. The defendant's counsel, on the other hand, stressing that his client was clean, claimed that some other man must have infected the child with gonorrhoea. Barber was freed by the jury, but had to pay the costs of his defence, while the child "was stigmatized as a young prostitute". The management of five other cases in the 1853 epidemic was more fortunate. When the nature of the condition was explained, the parents ceased to direct their suspicions towards neighbours, fellow-lodgers, etc. 


\section{Sir William Wilde's Medico-Legal Observations}

part of the crown to make out a case." The paper commented that when revolting crimes occurred it was important that the perpetrators should be severely punished, but unless such cases could be fairly and distinctly proved it was equally important "that the ears of a Green-street auditory, even such as it is, should not be poisoned by details of circumstances such as we allude to".

The newspaper referred to a disease of female children "partly induced, and perhaps aggravated by uncleanliness". The evidence of Cusack and his colleagues was regarded favourably, while the prosecution was chided: "The bench, however, and the crown lawyers, who did not seem perfectly to understand the anatomical or pathological details of the medical men, were, as it appeared to us, rather prejudiced against the prisoner-". 44

The newspaper referred to the trial again on 8 August, possibly at the instigation of Dr Ireland, saying a misconception may have arisen: "We have been asked how it arose that the medical witnesses examined for the crown and those examined for the accused differed so essentially in their opinion." It pointed out that the doctors had not really contradicted each other. Dr Ireland's sworn information before Mr Richard Bourke enunciated "in the most express terms" that the symptoms which aroused the mother's suspicions "might arise from want of cleanliness", and that the accused man was "not at all diseased". Dr Ireland's informations were in accordance with the views of the defence. $^{45}$

Wilde availed himself of the opportunity to comment: his letter to the editor insisted "that no misconception whatever need arise". The medical witnesses for the crown and the defence had differed materially. Ireland had held "that the appearance presented 'may have been caused by some violence".' He brought up the police doctor's refusal to allow him to be present during the children's examination, and mentioned a discrepancy between what the girls swore before the magistrate and what appeared in the information. To the former the children said that the alleged rapes occurred at "the self same day and hour", while in the latter a date of three days later was asserted to have been given by the Delmere child. Both children ("being tutored, as I believe, into the recital of the same story") had given identical accounts, and this was seen and altered by whoever drafted the informations. The existing system of "medical police" was defective and required reform. ${ }^{46}$

In conclusion [Wilde wrote], I beg to say that I conceive it to be the duty of a medical man called in by the police to make himself well acquainted with the medical jurisprudence of the case he is required to investigate, as very often upon it, and it alone, has the magistrate to adjudicate. I think it to be his duty to afford negative as well as positive evidence, and to inform the magistrate, when cases like this under discussion are submitted to his inspection, that the disease which, to use the words of your paper this day, "gave rise to the unnatural suspicion of the mother," affords of itself no evidence of attempted violence, but is an affection peculiar to a certain class of children. ${ }^{47}$

\footnotetext{
44 The Freeman's Journal, 6 Aug. 1853, p. 2. Founded in Dublin in 1763, "The Freeman" was an influential Irish daily newspaper which supported Catholic Emancipation, the Land League, Home Rule and parliamentary nationalism. It was incorporated into the Irish Independent in 1923.

45 Ibid., 8 Aug. 1853, p. 2.

46 The term "medical police" is an eighteenthcentury German coinage and most clearly expressed
}

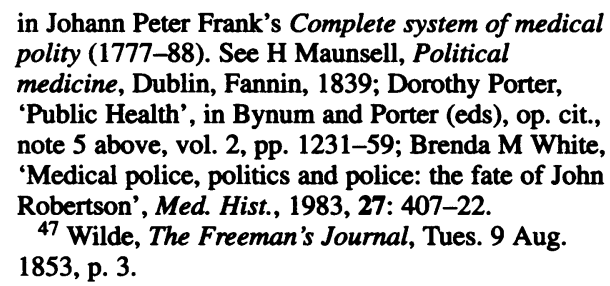
polity (1777-88). See H Maunsell, Political medicine, Dublin, Fannin, 1839; Dorothy Porter, 'Public Health', in Bynum and Porter (eds), op. cit., note 5 above, vol. 2, pp. 1231-59; Brenda $M$ White, 'Medical police, politics and police: the fate of John Robertson', Med. Hist., 1983, 27: 407-22.

47 Wilde, The Freeman's Journal, Tues. 9 Aug. 1853 , p. 3. 
Replying, R S Ireland claimed his informations had given the crown the opinions of medical jurists "as to the possible causes of such appearances". He affected to be puzzled that Wilde should "take umbrage at my not in the first instance having consulted him", a course that would have been "highly objectionable", as the prisoner was his own servant. He had seen the children later with Wilde and Dr Geoghegan, but by then the treatment ordered had "somewhat altered the character of the affection". By now he had stated all he knew of this case, and "must, for the future, decline taking any further notice of further publications on the subject". 48

Wilde wrote again to say that whatever treatment Ireland had prescribed could not have made any substantial change in the appearance of lesions which Dr Geoghegan swore he believed to be of several weeks' duration, and which the child's mother swore at the trial were still present. ${ }^{49}$

Clearly, more needed to be done- "as it concerns the safety of the community"- and the fuller account in a suitable journal, promised by Wilde to The Freeman's editor, was already in the making. His detailed account of the ill-starred Dublin epidemic appeared in the Medical Times and Gazette, and was re-published as a pamphlet at the end of the year. ${ }^{50}$ His principal authorities were Sir Astley Cooper, Mr Kinder Wood, ${ }^{51} \mathrm{Mr}$ (later Sir William) Lawrence and others. ${ }^{52}$ Wilde believed it to be "our duty as public journalists"53 to ventilate the matter for the education of inexperienced doctors; to expose "the deficient system of medical police in the United Kingdom"; and as a warning for lawyers and public prosecutors. He wished, too, to wipe out "the foul national stain of having it alleged, that four children were violated in our city within the space of two or three months". 54

${ }^{48}$ R S Ireland, ibid., Wed. 10 Aug. 1853, p. 3.

49 Wilde, ibid, Sat. 13 Aug. 1853, p. 3.

50 Op. cit., note 13 above. The preface is dated 1 Dec. 1853. Elsewhere Wilde gave 1853 as publication year whereas The British Library Catalogue has 1854.

${ }^{51}$ On Kinder Wood, MRCS, of Oldham, Lancs., see E M Brockbank's A centenary history of the Manchester Medical Society, Manchester, Sherratt \& Hughes, 1934. Kinder Wood's communication, 'History of a very fatal affection of the pudendum', Med.-Chir. Trans., 1816, 7: 84-102, was presented by Mr John Abernethy (1764-1831) to the Medico-Chirurgical Society of London on 12 December 1815 . It describes the most acute and dangerous form of vulvo-vaginitis (10 of the Oldham surgeon's 12 cases died), later named noma pudendi. This "extremely fatal" disease did not resemble either syphilis or gonorrhoea. Wood was struck by its insidious onset, its rapid progression, "its novelty". Commencing with "chilliness succeeded by heat" and headache — an onset that today suggests infection-inflammation of the pudendum soon presents. "From this period of the formation of the inflammation so rapid is the progress to ulceration, that scarcely twenty-four hours elapse before a number of small vesications forming within the labia, as well as externally, burst and form so many open surfaces which, quickly spreading into each other, form larger ulcers". A copious discharge from ulcerated surfaces extends the disease "along the perineum to the anus, and to the inner part of the top of the thigh, contiguous to the labia. I have also seen the inflammation spread over the mons Veneris, and be succeeded by deep ulcerations progressively extending as long as life continued." The face is pale, "the skin having a singular whiteness". See also, Thomas Percival, Medical ethics, Manchester, Johnson, 1803, p. 32.

52 William Lawrence, 'Peculiar affection of the genitals in female children', Med. Gaz, 1830, 6: 828. He described a disorder which "has been in many instances confounded with syphilis ... and hence have arisen, in some cases, suspicions that children have been ill-used; in fact, that persons have had connexion with them, and imparted to them the venereal disease; consequently, in some cases, judicial trials have been the result." See also, William Moss, 'Purulent urethral discharges in children', Lancet, 1835-6, i: 448;

A T Thomson, Lecture XII on medical jurisprudence, discussed appearances in females simulating the effects of rape, ibid., 1836-7, i: 449-54, on pp. 452-4.

53 It is unlikely that Wilde aspired to be a medical jurist, but feeling a civic obligation he turned instinctively to his natural medium. Catherine Crawford has described the "self-consciously central role" of the medical press in the development of forensic medicine. The medical journals offered "a sort of professional tribunal, and a forum for debate, providing critical reviews and imposing rules on the process of evaluation". Crawford, op. cit., note 8 above, pp. 203-30.

${ }^{54}$ Wilde, op. cit., note 12 above, p. 262. 


\section{Sir William Wilde's Medico-Legal Observations}

This aspiration appears oddly innocent at the present day, when child sex abuse and assault are recognized to have epidemic proportions internationally. The circumstances, however, were very different then and now when it is accepted that vulvo-vaginitis is a not uncommon disorder of childhood. ${ }^{55}$

\section{Leucorrhoeal Ophthalmia}

Early in 1857, Wilde reported that infantile leucorrhoea had affected even prosperous families. ${ }^{56} \mathrm{He}$ confirmed that leucorrhoea could lead to purulent ophthalmia, citing an instance where a nursery sponge conveyed an infection from a child with a genital discharge, to her sister's eye. ${ }^{57} \mathrm{He}$ reported, too, a bizarre situation where a respectable married couple developed discharges which (after considerable reciprocal recriminations) were finally explained by the discovery that their little girl, who sometimes slept with her mother, had leucorrhoea, and was the innocent source of infection. Here, perhaps, we see Wilde at his most credulous, apparently giving little serious consideration to the alternative possibility that the mother, infected by her husband, might have conveyed the condition to the child.

Wilde intervened on behalf of a businessman and a railway clerk. The former was accused of assaulting his little sisters-in-law aged about two and seven, who, according to their medical-student brother and a doctor whom the latter called in, "were clapt". The head of the firm appealed to Wilde, who in turn summoned Professor T E Beatty. ${ }^{58}$ "We examined the [elder] child in the presence of the mother. She exhibited no marks of violence whatever, but laboured under mild leucorrhoea." 59

The railway clerk was accused of a felonious assault upon a nine-year-old girl. She had made no complaint against him, but her mother noticed her stained linen and during an interrogation extracted the information that he had given her a penny as a Christmas-box. The crime was alleged to have been perpetrated in the parcel-office, during rush hour on Christmas Eve, and under the glare of the gaslight with a large crowd of passengers about.

Wilde appeared for the prisoner; on this occasion he and Dr Ireland were in agreement. It emerged that the father had told the child "the name of the man she was to swear against as they walked to the court". ${ }^{60}$ She contradicted herself repeatedly, and the mother was sent out for prompting her. The magistrate dismissed the case.

\footnotetext{
55 It is nowadays realized that a female child's attenuated external genitalia and the acidity of the vaginal secretions result in a susceptibility to vulvovaginitis, the commonest condition seen at a paediatric gynaecology clinic. See A S Garden in Forfar and Arneil's textbook of paediatrics, 4th ed., eds A G M Campbell and Neil McIntosh, London, Churchill Livingstone, 1992, p. 1073.

56 Wilde, 'Leucorrhoeal ophthalmia, and other cases of infantile leucorrhoea', Med. Times Gaz., 1857, 14: 58-60.

57 This case is cited in the 3rd edition $(1868$, p. 43$)$ of Guy's textbook (see note 9 above): "Wilde of Dublin describes a similar affectation of the parts of generation of young children in connection with
}

leucorrhoeal ophthalmia, and adduces facts to prove that both affections are contagious."

58 Though he had some interest in medical jurisprudence (see note 7 above), Beatty, author of Contributions to midwifery (1866), was an obstetrician with a large upper-class practice, and professor of midwifery in the RCSI (1842-57). He was PRCSI in 1850-51, and president of the College of Physicians in 1864-65, the only person to have held the highest office in both Colleges. He possessed a sweet tenor voice and sang regularly at the dinner parties given by the Wildes.

59 Wilde, op. cit., note 56 above, p. 60.

60 Ibid., p. 59. 
The attorney-general had dealt sensibly (as Wilde saw it) with another rural suspect: "instead of directing the whole force, and, let me add, ignorance of the law, to be brought to bear against the accused person, he ordered the Crown Solicitor to lay the facts before a Medical man in the metropolis, versed in such cases . . . That I look upon as a great step in advance." ${ }^{61}$ But perhaps Wilde was becoming over-zealous, and over confident in his self-appointed role of defender.

\section{Noma Pudendi}

The cavalier attitude towards medical evidence which was his experience at Green Street Court House was likely to remain in Wilde's mind, and when on 7 December 1857 he read in The Times an account of the trial in Liverpool before Sir William Wightman (1784-1863) of a young Englishman, Amos Greenwood, for the alleged rape and murder of a child, he suspected a miscarriage of justice. He wrote to William Lawrence ${ }^{62}$ who agreed that a mistake seemed likely and urged Wilde to communicate with the trial judge, as he himself had already done. Wilde wrote to Judge Wightman, to the lawyers, and also to the doctors who had treated the girl. He "empanelled" a jury of twelve medical men, sending a questionnaire to distinguished colleagues. Eventually he wrote to the Home Secretary, and, when the latter failed to respond to his appeal, he published an account of the case. 63

The brutal events narrated in The Times concerned a group of five: a costermonger named Handcock, his wife Betty and their baby; Mary Johnson who was employed to mind the infant-she was not yet ten years old but according to the newspaper "was described as much taller and more fully developed than the generality of children of that age"; 64 and Greenwood, the recently hired assistant. The time was the autumn of 1857 , the mise-en-scène the fair-grounds and market-places of Lancashire.

Arriving on Thursday 22 October at Heap, a village near Manchester, where a fair was about to be held, the five put up at a lodging-house. That night, following an arrangement dictated by convenience and economy, they slept in a small room in which there were two beds placed close together, one occupied by the Handcocks and their child, and the other by Amos Greenwood and Mary Johnson. The girl went to bed at 7.30 p.m.; Greenwood retired at about 9.30 and was joined within the next half hour by the Handcocks. There was no disturbance whatever during the night, and later it was recalled that on Friday morning before setting off for Wigan, where they lived in the "Pig Market", Mary appeared to be in perfect health. Betty Handcock testified that the bed was unstained.

\footnotetext{
61 Ibid.

62 Sir William Lawrence, Bart. (1783-1867), surgeon to St Bartholomew's Hospital for more than forty years, was much senior to Wilde, but they had a mutual interest in ophthalmic surgery. Lawrence wrote extensively on anatomy, surgery etc. (see note 52 above), but was also surgeon to the London Infirmary for Diseases of the Eye and author of a Treatise on diseases of the eye.

63 Wilde, 'Medico-legal observations upon the case of Amos Greenwood, tried at the Liverpool Assizes,
}

\begin{abstract}
December, 1857 , for the wilful murder of Mary Johnson, and sentenced to penal servitude for life', Dublin quart. J. med. Sc., 1859, 27: 51-87. Wilde's correspondence with the judge and others has not survived. He wrote to Judge Wightman on 11 Dec. 1857 and again on 30 Jan. 1858; the judge replied on 19 Dec. 1857. Sir William Wightman had a reputation for having "an abundance of good sense" (DNB).
\end{abstract}

${ }^{64}$ The Times, 7 Dec. 1857 , p. 9. 


\section{Sir William Wilde's Medico-Legal Observations}

The child limped on Sunday evening, and seemed in pain, complaining of a "smarting in her thighs". She was sent to bed and an examination by Betty Handcock revealed sore external genitals and excoriated thighs. Next day a Wigan surgeon, Mr J T Winnard, MRCS Eng., LSA, diagnosed vaginitis and said she would need a lot of attention. When asked if swallowing a sixpence could have caused it, Winnard said "Certainly not!" but no more serious cause was considered. ${ }^{65}$

The costermongers moved to Heywood where Mary Johnson's condition deteriorated. Her employers and the fair-ground women pressed her to confess to the cause of her ailment, asking if any boy had been playing with her, or "if some lad had been putting his hand up her coats"? but she persisted that she had nothing to confess. Finally she was told that unless she confessed she would be left to die. "It is asserted [Wilde wrote] that she then stated that upon the night when they all slept in the same room at Heap, and while in the bed adjoining her mistress, her bed-fellow, Amos Greenwood, had connexion with her, and produced the violence which her person then exhibited."66

J B Jameson, ${ }^{67}$ of Heywood, whom Wilde refers to disparagingly as a "druggist", gave mercury but "sloughing and mortification advanced rapidly"; a local surgeon, $\mathrm{J}$ W Pickford, MRCS, Eng., LSA, substituted quinine but a destructive, devitalizing process spread to the buttocks and abdomen. The child died on 5 November. Greenwood was arrested and found to suffer from venereal warts and syphilitic sores. ${ }^{68}$ At the trial in Liverpool, ${ }^{69}$ Jameson of Heywood gave evidence that death resulted from "mortification of the genitals brought on by laceration, inflammation and venereal poison". ${ }^{70}$ The judge pointed out that "it mattered not whether she was a consenting or a resisting party if she were under ten years of age", and after retiring for about an hour, the jury found Greenwood guilty of manslaughter. He was sentenced to penal servitude for the term of his natural life. ${ }^{71}$

Sir William Wightman's reply to Wilde's letter left him even more certain that Greenwood was wrongly accused, for the judge explained that it was "proved to the satisfaction of the jury that the prisoner, who slept with the deceased, a female child of nine years of age, had forcible connexion with her, and that her private parts had been dreadfully lacerated, and the perineum ruptured . . .". ${ }^{72}$ How could this be reconciled, Wilde asked, with Mary Johnson's well-being on the Friday morning? She did not cry out and the bed was unstained. Neither syphilis nor gonorrhoea would act in this way, and Wilde believed the child died from a spontaneous inflammatory and gangrenous process, noma pudendi, a rare disease the provincial practitioners might never have seen.

Subsequently he confirmed that neither of the Heywood practitioners knew this dreadful condition, a disease analogous to cancrum oris, a condition still listed in medical textbooks but excessively rare. Cancrum oris and noma pudendi still occur in developing

65 Wilde, op. cit., note 63 above, p. 63.

66 Ibid., p. 52.

67 John Bland Jameson was Pickford's assistant; his name was entered in the medical register on 27 April 1859-Licentiate of the Faculty of Physicians and Surgeons of Glasgow (1859); he became LRCP Edin. in 1860. See Medical directory, 1857 to 1860.

68 Wilde, op. cit., note 63 above, p. 55.

\footnotetext{
${ }^{69}$ Legal procedures in Liverpool did not differ from those in Dublin.

${ }^{70}$ Wilde, op. cit., note 63 above, p. 53. In his letter to Judge Wightman, Wilde questioned Jameson's competence to make a post-mortem examination adequate for medico-legal purposes.

${ }^{71}$ The Times, 7 Dec. 1857 , p. 9.

72 Wilde, op. cit., note 63 above, p. 53.
} 


\section{J B Lyons}

countries; the latter is characterized by inflammation progressing rapidly to extensive ulceration of the pudendum spreading along the perineum to the anus, and anteriorly to the mons veneris. The external genitals are destroyed and the exhausted patient expires. ${ }^{73}$

On 13 April 1858 the Home Secretary, the Rt Hon. Spencer Horatio Walpole, rejected the request for a further enquiry, as he could not see a "sufficient reason for doubting the propriety of the verdict". He added that since the trial neither the prisoner, nor his friends, had asserted innocence, causing Wilde to throw up his hands despairingly. "Whether this wretched, illiterate, costermonger's assistant may have any friends," he wrote, "or if he have, whether they are imbued with a belief in his innocence, and able and willing, in the absence of a cheap criminal court of appeal, or a Minister of Justice, to bring the matter under the notice of one of her Majesty's Ministers, is really more than I care to inquire about". ${ }^{74} \mathrm{He}$ urged the necessity of professional coroners ${ }^{75}$ instructed in medical jurisprudence, and the provision of a Court of Criminal Appeal. ${ }^{76}$

Wilde's questionnaire evoked varied replies. Thomas Byrne, surgeon to Dublin's Lock Hospital, answering one question only, affirmed that he had never seen a fatal case of primary syphilis "attended with sloughing, ulceration, and mortification of the genitals". 77 Seven doctors accepted that Mary Johnson died from noma pudendi. ${ }^{78}$ The four who disagreed were William Acton, Sir Benjamin Brodie, W B Kesteven and A S Taylor. Acton, author of The functions and diseases of the reproductive organs (1857), attributed death to sloughing phagedena and this, too, was Kesteven's diagnosis; Brodie avoided committing himself to a diagnosis but expressed the opinion "that there is great reason to believe that the charge against the prisoner, so far as his having made attempts to have sexual intercourse with the girl, was not without foundation"; 79 Taylor attributed death "to inflammation from violence alone to the genital organs". 80

Kesteven, a London surgeon with an interest in forensic medicine, challenged Wilde in the Medical Times and Gazette, suggesting that he "has suffered a preconceived opinion

\footnotetext{
${ }^{73}$ On cancrum oris see Thomas Cumings, 'Observations of an affection of the mouth in children', Dublin Hosp. Reps., 1827, 4: 330-47. Cumings, a physician attached to the Institution for the Diseases of Children, described this disorder "which has been but cursorily noticed by authors". He recognized three forms ranging in severity from gingivitis to a highly destructive condition which "seems to resemble, in many respects, that gangrenous inflammation of the pudendum in children, of which so excellent a description has been given by $\mathrm{Mr}$. Kinder Wood" (see note 51 above). See also, William Dease, Observations in midwifery [and] On the principal disorders incident to women and children, Dublin, Williams, 1788. For a modern account of the disease, with historical review, see Michael N Tempest, 'Cancrum oris', Brit. J. Surg., 1966, 53: 949-68. Fusiformis fusiformis and Borrelia vincenti can be isolated in most cases; malnutrition is commonly associated and the lesions may follow measles. J B Macdonald has suggested ('On the pathogenesis of mixed anaerobic infections of mucous membranes', Ann. R. Coll. Surg. Engl., 1962, 31: 361-78) that the key pathogen in mixed anaerobic infections of mucous membranes is Bacteroides melaninogenicus.
}

${ }^{74}$ Wilde, op. cit., note 63 above, p. 85 .

75 Thomas Wakley, the Lancet's editor, also advocated medical coroners; not until the Coroners Amendment Act of 1926 were they required to be barristers, solicitors, or legally qualified medical practitioners.

76 The Criminal Appeal Act (1907) created a Court of Criminal Appeal to take over the jurisdiction formerly exercised by the Court for Consideration of Crown Cases Reserved.

${ }^{77}$ Wilde, op. cit., note 63 above, p. 72 . It may be argued that as the majority of the recipients of the questionnaire were Dubliners, and may have heard him discuss the matter, Wilde had unwittingly introduced a bias in favour of his own opinion. Acton and Kesteven, on the other hand, appear to have been entirely speculative in offering a diagnosis of phagedena.

78 They were Beatty, Churchill, Geoghegan, Lawrence, Alfred M'Clintock, Master of the Rotunda Lying-in Hospital, John H Power, a Dublin surgeon, and James Young Simpson of Edinburgh.

${ }^{79}$ Wilde, op. cit., note 63 above, p. 79.

80 Ibid., p. 77. 


\section{Sir William Wilde's Medico-Legal Observations}

to obscure his judgement". ${ }^{81}$ Kesteven believed "there can be little room to doubt that the attempt at intercourse was made, but that the prisoner desisted before the child's cries were loud enough to wake the sleepers". Death resulted, he believed, from "syphilitic inoculation, the disease having assumed the most virulent form" ${ }^{82}$

Wilde's polemic reply took Kesteven up on trivial errors in the latter's paper, dismissed the opinion that some "attempt at intercourse" was made as an inference not acceptable in a court of justice, and rebuked him for arguments "which I certainly did not expect to find adopted by a man of science, as a medico-legal reason against a person's innocence". His most valid points were that the lawyers in Liverpool knew nothing of leucorrhoea, vaginitis, noma pudendi, or the medico-legal bearings of the case, and that the symptoms Mary Johnson presented were not those of a venereal complaint. "She complained of great pain . . . a symptom scarcely ever observed in primary syphilis." 83

Wilde should have given greater weight to A S Taylor's opinion. He was the United Kingdom's leading authority in medical jurisprudence, and he believed Greenwood to be guilty of rape. Taylor subsequently referred to the case in The principles and practice of medical jurisprudence (1865): "The propriety of this conviction has been strongly questioned by Sir William Wilde . . . but there is no reason to doubt that the prisoner was accessory to the death of the child."84 The jurist had spoken to a QC who was not involved in the trial but heard all the evidence, and regarded Greenwood as properly convicted.

\section{Greek Tragedy}

Wilson did not mention Wilde's medico-legal observations in Victorian doctor (1942). ${ }^{85}$ Discussing the Greenwood case briefly, Terence de Vere White seemed determined in The parents of Oscar Wilde (1976), to cast William Wilde as a player in a Greek tragedy, in which the later heroic parts were taken by his son, Oscar. White reduced the possibility of objectivity by introducing a metaphor of "dragons' teeth" fated to erupt embarrassingly in the Travers libel suit, ${ }^{86}$ and having overlooked the pamphlet on Infantile leucorrhoea he was unaware that Wilde's loyalty to his coachman had originally enlisted his interest in these pitiable cases. ${ }^{87}$

Wilde's sympathy for Amos Greenwood remains difficult to understand. The circumstantial evidence weighed heavily against Greenwood, whose parsimonious

${ }^{81} \mathrm{~W}$ B Kesteven, 'On the evidence of rape on infants, with remarks on the case of Amos Greenwood', Med. Times Gaz., 1859, 18: 361-3, 417-19, 442-4.

82 Ibid., p. 363.

83 Wilde, 'Observations on Mr. Kesteven's remarks on the evidences of rape on infants', Med. Times Gaz, 1859, 18: 518-20, 544-6. See also, J Brown, 'Evidence of rape on infants', ibid., p. 638, and Wilde's reply, ibid., 1859, 19: 21-2; C E Bagot, 'Some remarks on laceration of the perineum, and on noma pudendi', Dublin med. Press, 1859, 41: 101, 129-30.

84 A S Taylor, The principles and practice of medical jurisprudence, London, Churchill, 1865, p. 995.

${ }^{85}$ T G Wilson (see note 2 above), was an ENT surgeon; his passion for yachting and painting reduced further the limited time available for biographical research, and may explain why he overlooked the medico-legal observations. He was president RCSI 1958-60.

${ }^{86}$ The libel action, heard 12-17 Dec. 1864, was reported in Dublin med. Press, 1864, 52: 601-3, 622-6. See also, 'The case of Travers versus Wilde', Lancet, 1864, ii: 720-1.

${ }^{87} \mathrm{~T}$ de Vere White (see note 2 above) practised law before devoting himself fully to writing as novelist, biographer and literary editor of the Irish Times; it is regrettable that because he overlooked all but one of the medico-legal articles we do not have the benefit of his legal opinion on the merits of Wilde's interventions. 
employers obliged him to share a bed with the female child in the sordid lodging-house, and Wilde should have recalled the fate of John Hamilton's second patient, little Mary McCormick. ${ }^{88}$ The six-year-old shared a bed with a youth (a nineteenth-century practice which Wilde himself condemned as far too common), who was subsequently accused of infecting her with syphilis. The child told her mother he "had turned her face to the wall and hurt her private parts with his finger". James Lucas, the nineteen-year-old defendant, said Mary was fond of him, and used to lie close to him. He denied "having ever attempted anything", but he was sore behind-condylomata were accountable_and "used to run 'a power of water', as she lay against his back". This, he claimed, had infected her. Doubt as to whether the unequivocal infection resulted from accidental contact, or as Hamilton believed, "wilful violation", may explain why the Recorder's sentence was only a year's imprisonment. 89

One cannot avoid wondering if Wilde's own amorous misadventures swayed his judgement, creating a bias toward the wayward. (He was the father of three natural children, ${ }^{90}$ and his unwise friendship with a former patient was to involve him in a libel suit in 1864.) This seems unlikely. He had not yet met Mary Josephine Travers ${ }^{91}$ when the 1853 epidemic had such unfortunate results; four years later, when Greenwood was sentenced, the Travers-Wilde relationship was still amicable. It is, however, not unlikely that when Miss Travers sued the Wildes for Lady Wilde's libel, Sir William's decision not to appear as a witness was influenced by what he had already learned of the law.

Wilde's diagnosis of noma pudendi was probably correct, but his willingness, in the circumstances, to accept the process as entirely spontaneous is surprising. Today, nutritional, immunological and bacteriological factors would be invoked, and the necrotic process may have been initiated by trauma. When Mary Johnson was urged in Heywood to confide in Jameson, she said that during the Thursday night she woke to find Amos Greenwood lying on her: "and that he put his 'fie-for-shame' into hers; that he kept moving about upon her, she thought, about half an hour; she frequently told him to get off her, but he still continued; and that just before he did so, all at once he gave her great pain, and she felt as if she had been cut open with a knife."92

That confession has the ring of truth, and the child's failure to scream may indicate a dazed acceptance of her fate, in the rough tradition of the fair-grounds. Wilde, however, could not believe there had been what he called "an 'allowed connexion' (a crime of equal guilt in the sight of the law, when committed upon a girl of this tender age)". ${ }^{93} \mathrm{He}$ felt she had been obliged to fabricate the rape by the clamour of the costermongers' wives, just as the little Dublin girls were remarkably inventive once they yielded to their mothers' threats and pleadings.

\footnotetext{
${ }^{88}$ Hamilton, op. cit., note 19 above, p. 277.

89 Ibid.

90 They were Dr Henry Wilson and two girls, Emily and Mary, who were given their father's surname and lived with their uncle, the Rev. Ralph Wilde in County Monaghan. For an account of Wilde's natural son (and assistant at St Mark's Hospital), see J McAuliffe Curtin, 'Henry Wilson, M.D., F.R.C.S.I.', Irish J. med. Sc., 7th series, 1969, 2: 369-78.

91 The daughter of Dr Robert Travers, lecturer in medical jurisprudence at Dublin University, she was
}

nineteen when Dr William Stokes referred her to Wilde in July 1854 for a hearing problem. A warm friendship followed; when it cooled she attacked the Wildes in scurrilous pamphlets, and used Lady Wilde's letter of rebuke and complaint to her father as the basis of a suit for libel. During the hearing she alleged that Wilde had raped her. The jury agreed that she had been libelled by Lady Wilde but assessed damages at a farthing.

92 Wilde, op. cit., note 63 above, p. 65.

93 Ibid., p. 83. 


\section{Sir William Wilde's Medico-Legal Observations}

His response to Amos Greenwood's life-sentence was prompted by the Lancashire practitioners' mis-diagnosis, and sustained by sympathy for the underdog. It was influenced, too, by a factor of gender, thus providing an early example of the appalled public incredulity and denial which was to be the commonest reaction in the 1980s to the disclosure that child sexual abuse exists in epidemic proportions. ${ }^{94}$

\section{Conclusion}

Wilde's Medico-legal observations upon leucorrhoea was written primarily to educate doctors and lawyers, and to eliminate facile accusations directed at innocent men. It was soundly based, commendable and influential.

In the 4th edition (1857) of his text-book, ${ }^{95}$ Fleetwood Churchill revised the section on leucorrhoea, remarking that several cases "have been made the subject of criminal information ... and have been published with much useful information, by Dr. Wilde." Churchill added a substantive account of rape in children. A S Taylor paid a tribute to Wilde in the 8th edition of his Manual of medical jurisprudence (1866): "Infantile leucorrhoea has been fully investigated by Sir William Wilde of Dublin. This gentleman has collected numerous instances illustrating in a remarkable manner the great danger to which innocent persons are exposed by reasons of false charges of rape on children". 96 But perhaps the concern for the innocent, however understandable, shown by these nineteenth-century authors, from Cooper to Wilde and Taylor, serves today to underline the validity of Susan Brownmiller's observation: "The most bitter irony of rape, I think, has been the historic masculine fear of false accusation, a fear that has found expression in male folklore since the biblical days of Joseph the Israelite and Potiphar's wife . . ".97

Wilde's motivations included compassion for the mothers. The latter, convinced that a crime had been committed, were determined to have the accused men punished, and to achieve this they were prepared to tutor affected children in matters few prostitutes would willingly discuss. ${ }^{98} \mathrm{He}$ disapproved of an adversarial legal system intent on winning the case rather than on reaching the truth.

His intervention on Amos Greenwood's behalf was a logical, if over-enthusiastic, sequel to his earlier work; and if it is not possible to accept Wilde's belief that Greenwood did not violate the child, it is at least clear that his diagnostic acumen recognized noma pudendi as the cause of death, a freak of nature, an untoward and lethal tissue reaction to insults sometimes so trivial as to make the process seem spontaneous, rather than the gross

\footnotetext{
94 Beatrix Campbell, Unofficial secrets-child sexual abuse, the Cleveland case, London, Virago, 1988 , passim. On child abuse see also, Neil O'Doherty, The battered child, London, Baillière Tindall, 1982; Diana E H Russell, Sexual exploitation: rape, child sexual abuse and workplace harassment, London, Sage, 1984; Anon., Lancet, 1987, i: 367-8; Jan E Paradise, 'The medical evaluation of the sexually abused child', Pediatr. Clin. N. Am., 1990, 37: 839-62.

95 Churchill, op. cit., note 11 above, p. 50.

96 Taylor, op. cit., note 9 above, p. 598.

97 Brownmiller, op. cit., note 9 above, p. 386.
}

\begin{abstract}
98 "How does it happen [Wilde asks, op. cit., note 12 above, p. 448], that in no instance does the child ever tell what has occurred until interrogated or threatened by the mother? She has neither love nor lust to influence her. She has no feeling of shame to cause her to withhold the desired information; and yet it is supposed that, for a 'bit of sugar,' or a 'pennyworth of strawberries,' she (who may have been heretofore truthful, affectionate and obedient,) will withhold from her friends the name of her ravisher for days together, or until compelled to give it up by threats or punishment; or that she only remembers the name when mentioned to her?"
\end{abstract}




\section{J B Lyons}

brutality pictured erroneously by Judge Wightman. Wilde had no intention of condoning rape, which he condemned as "one of the gravest offences which can be committed against society, public morals, or an individual". 99

${ }^{99}$ Wilde, op. cit., note 13 above, p. v. 